\title{
Antimicrobial Activity of Some Selected Medicinal Plants in Some Northern Parts of Bauchi State, Nigeria
}

\author{
Aska A.S. ${ }^{1^{*}}$, Kubmarawa D. ${ }^{2}$ Nkafamiya I.A ${ }^{3}$, Shagal H.M ${ }^{4}$ \\ ${ }^{1}$ Aminu Saleh College of Education Azare, Bauchi State Nigeria \\ 2, $3 \& 4$ Modibbo Adama University of Technology Yola, Adamawa State Nigeria.
}

*Corresponding Author: Aska A.S. , Aminu Saleh College of Education Azare, Bauchi State Nigeria

\begin{abstract}
Antimicrobial activity of some medicinal plants traditionally used by local communities in the treatment of tuberculosis and other respiratory diseases was carried out. The antimicrobial activity of the plants extracts against some microbial pathogens was investigated as preliminary study to screen the plants for their anti-tuberculosis activity. The antimicrobial test was done using agar disc diffusion method and the minimum inhibitory concentration (MIC) was also determined by Micro broth dilution method. The result indicated that the extracts had varied activity against the tested organisms. The extracts also showed dose dependent antimicrobial activity but significantly lower than the standard antibiotic drugs (ciprofloxacin and Ketoconazole). The extract of E. hirta has no activity against E. coli at the tested concentrations but shown the zone of inhibition range from $10-16 \mathrm{~mm}$ for other tested organisms. E. hirta has MIC of $15 \mu \mathrm{g} / \mathrm{ml}$ against K. pneumonia and C.albicans and $30 \mathrm{mg} / \mathrm{ml}$ for B.subtilis, S. typhi and S aureus. The extract of C. mucronata has shown zone of inhibition range from 12- 16mm but it has no activity against $B$. subtilis at the tested concentrations. It has MIC of $15 \mu \mathrm{g} / \mathrm{ml}$ against C.albicans, B. subtilis, K.pneumonia, E.coli and 30 $\mu \mathrm{g} / \mathrm{ml}$ against $S$. aureus. The stem bark extract of $X$. americana has shown the zone of inhibition range of 10-16mm and active against all the tested organisms. It has MIC of $15 \mu \mathrm{g} / \mathrm{ml}$ against S. aureus and K. pneumonia. The leaf extract of $W$. indica has shown zone of inhibition ranging from 11-16mm. It was active against all the tested pathogens and exhibited MIC of $15 \mu \mathrm{g} / \mathrm{ml}$ against $S$. aureus and C. albicans. The leaf extract of $P$. reticulatum has shown the zone of inhibition ranges from $9-15 \mathrm{~mm}$ against the tested organisms. It exhibited MIC of $15 \mu \mathrm{g} / \mathrm{ml}$ against S. typhi. The aerial parts extract of S. hermonthica has shown zone of inhibition ranges from 12-16mm. The extract has shown the zone of inhibition (12, 14 and 16mm) against C. albicans at the concentration of 15,30 and $60 \mu \mathrm{g} / \mathrm{ml}$ respectively. But the extract has no activity against $S$. typhi at the tested concentrations. The extract has MIC of $15 \mu \mathrm{g} / \mathrm{ml}$ against B. subtilis and $C$. albicans. The extract of T. indica has shown the zone of inhibition ranges from 10-15mm. But the extract has no activity against $C$. albicans at all tested concentrations. It has MIC of $15 \mu \mathrm{g} / \mathrm{ml}$ against K. pneumonia and E.coli. The extract of E. senegalensis has shown the zone of inhibition ranging from 11-14mm. However the extract has no activity at the lowest concentration of $15 \mu \mathrm{g} / \mathrm{ml}$ against all the organisms except $S$. aureus. The extract has MIC of $15 \mu \mathrm{g} / \mathrm{ml}$ against $S$. aureus and $30 \mu \mathrm{g} / \mathrm{ml}$ against all other organisms tested. The leaf extract of B. paradoxum has shown a zone of inhibition of 16mm against E. coli and zone of inhibition ranges from 11- 16mm. The MIC of the extract against E. coli, S. typhi and B. subtilis is $15 \mu \mathrm{g} / \mathrm{ml}$ and $30 \mu \mathrm{g} / \mathrm{ml}$ for C. albicans. However the extract has no activity at all tested concentrations against $S$. aureus and $k$. pneumonia. The extracts that exhibited zones of inhibition greater than 10mm were considered active and therefore recommended for further screening to isolate and characterize the bioactive chemical constituents.
\end{abstract}

Keywords: Methanol extracts, antimicrobial activity, MIC, medicinal plants.

\section{INTRODUCTION}

Despite the influence of modern drugs the use of medicinal plants has remained a very important aspect of health care delivery system especially in rural areas. It was reported that $80 \%$ of world's population relies on traditional medicines as primary source of their medication (Newman, 2006). The plant based preparations were central to traditional practice of health care system where herbs and different parts of medicinal plants are employed. Medicinal plants have some medicinal values based on folkloric usage and information. It was reported that plants are natural reservoir of therapeutic agents use by the local communities in the treatment of many diseases (Akinniyi and Tella, 1991). The clinical success of plant-based drugs has rekindled interest in research into medicinal plants as potential sources of new drugs. In some countries like China, India and Vietnam the research in to 

Nigeria

medicinal plants has been fully developed and plant-based remedies have been incorporated as alternative or complementary medicines to supplement the modern drugs. However, in Nigeria like in most African countries the research into medicinal plants has not been given a desire attention as such the therapeutic potentials of these natural endowments were under-utilized (Ogundaini, 2005).

In fact, the phyto-chemical agents in medicinal plants were shown to be responsible for the observed therapeutic activity against the diseases caused by pathogenic infections. There were several plant extractives that demonstrated significant inhibitory activity against microscopic pathogens like bacteria, fungi and viruses (Malcolm and Sofowora, 1969; Kone et al., 2004; Sanogo, 2005; Hamza and Mbwabo, 2006; Kubmarawa et al., 2007; Tanaka et al., 2010). The screenings of medicinal plants for antimicrobial activity have shown that higher plants represent a potential source of novel antibiotic chemotypes (Copp, 2003; Katerere et al., 2003; Ogundaini, 2005; Kubmarawa et al., 2007). The plants were screened for the presence of bioactive chemical constituents and it was found that they contained phytochemical constituents like alkaloids, flavonois, sterois, terpenoids, glycosides, anthraquinones, saponins and tannins (Aska and Kubmarawa, 2016).

In the present study, we are reporting the antimicrobial activity of some selected medicinal plants used in the treatment of tuberculosis and related respiratory diseases in Northern parts of Bauchi state, Nigeria.

\section{MATERIALS AND METHODS}

\subsection{Plant Material}

The different parts of the selected medicinal plants were collected from Three (3) Local Government Areas in the Northern parts of Bauchi State, Nigeria using standard method. The freshly collected plant samples were conveyed in clean polythene bags to Biology Department, Abubakar Tafawa Balewa University, Bauchi for identification by a taxonomist who identified and classified the plants specimens and voucher specimens was prepared and deposited in the Departmental Herbarium (Abdalfatah, et al., 2013; Zailani, et al., 2010; Mann, et al, 2008a; Kubmarawa, et al.,2007).

\subsection{Drying and Pulverising}

The samples of different parts of the plants were dried under shade inside a room. The fresh samples were spread out and turned regularly to dry them properly. The well dried samples were pulverized to fine powder using a wooden mortar and pestle. The powder of each sample was weighed using analytical balance and kept at room temperature until use (Ibrahim, et al., 2012).

\subsection{Extraction}

The plants samples were subjected to exhaustive extraction using soxhlet extractor. One hundred grams $(100 \mathrm{~g})$ of each sample in $70 \%$ Methanol was used in the extraction process which lasted for $12 \mathrm{hrs}$. The crude extract of each sample was filtered and concentrated in an oven at $40^{\circ} \mathrm{c}$. The dried methanol extracts were then packed in glass bottles with proper labeling for future use (Trease and Evans, 1989).

\subsection{Extracts Preparation}

The different concentrations $(15,30$ and $60 \mu \mathrm{g} / \mathrm{ml})$ were prepared from $5 \mathrm{~g}$ each of the crude methanol extracts of the plant samples. These concentrations were used to test the antimicrobial activity of the crude extracts.

\subsection{Microorganisms Tested}

Micro-organisms tested are Staphylococcus aureus, Escherichia coli, Klebsiella pneumonia, Salmonella typhi, Bacillus subtilis and Candida albicans. The clinical isolates were obtained from Mallam Aminu Kano Teaching Hospital Kano, Nigeria. The micro-organisms were grown and cultured in microbiology Laboratory of Bayero University Kano (BUK) Nigeria.

\subsection{Antimicrobial Susceptibility Test}

The Agar disc diffusion method was used to evaluate the antimicrobial activity of the plants extracts (Mangoma, et al., 2010, Atikya et al., 2014). The bacteria were cultured in nutrient agar medium at $37^{\circ} \mathrm{C}$ for 24 hours. The fungal was cultured on dextrose agar medium inoculated at $25^{\circ} \mathrm{C}$ for 7 days. Ciprofloxacin and ketoconazole were used as standard reference antibiotic drugs for bacterial and fungal respectively. The agar discs were impregnated with the different concentrations $(60,30$ and 15 $\mu \mathrm{g} / \mathrm{ml}$ ) of the plants extracts. The inoculated medium was poured into sterile Petri dishes and 
Antimicrobial Activity of Some Selected Medicinal Plants in Some Northern Parts of Bauchi State, Nigeria

incubated at $25^{\circ} \mathrm{C}$ for 5 days. Ciprofloxacin $(30 \mu \mathrm{g} / \mathrm{ml})$ and ketoconazole $(30 \mu \mathrm{g} / \mathrm{ml})$ was impregnated into the disc as positive control for the bacteria and Candida albicans respectively. The disc impregnated with Dimethylsulphoxide(DMSO)(4\%) and methanol(95\% JHD) were used as negative control. All the Petri dishes were incubated at $37^{\circ} \mathrm{C}$ for 24 hours, after incubation the discs were observed for growth inhibitions against the tested microorganisms by the tested extracts. The diameters of inhibition were measured and recorded in Millimeters ( $\mathrm{mm})$.

\subsection{MIC Determination}

The minimum inhibitory concentration (MIC) was determined by Micro broth dilution method (Okwute, et al 2017). Prepared Muller Hinton broth was dispersed into test tubes and sterilized with autoclave at $121^{\circ} \mathrm{C}$ for $15 \mathrm{mins}$ then the broth was allowed to cool. Two fold serial dilutions were used to obtain concentrations of $60 \mu / \mathrm{ml}, 30 \mu / \mathrm{ml}, 15 \mu / \mathrm{ml}, 7.5 \mu \mathrm{g} / \mathrm{ml}$ and $3.75 \mu \mathrm{g} / \mathrm{ml}$ of the crude extracts. $60 \mu \mathrm{g} / \mathrm{ml}$ was initially made by dissolving $0.06 \mathrm{mg}$ of the crude extract in $10 \mathrm{ml}$ of DMSO to obtain $60 \mu \mathrm{g} / \mathrm{ml}$ from which subsequent concentrations were prepared using two fold dilutions. Methanol (70\%) was used as a negative control. The microorganisms sensitive to the tested extracts were inoculated and incubated for $24 \mathrm{hrs}$ at $37^{\circ} \mathrm{C}$ and the lowest concentration of the extracts that showed no visible growth was recorded as the minimum inhibitory concentration (MIC).

\section{Results OBTAined}

Table1a. Antimicrobial sensitivity test of crude methanol extracts of the samples

\begin{tabular}{|c|c|c|c|c|c|c|c|c|c|c|c|c|c|c|c|}
\hline $\begin{array}{c}\text { Test } \\
\text { organisms } \\
\text { used }\end{array}$ & \multicolumn{3}{|c|}{$\begin{array}{l}\text { Conc }(\mu \mathrm{g} / \mathrm{ml}) \\
P . \quad \text { reticulatum } \\
(\mathrm{mm})\end{array}$} & \multicolumn{3}{|c|}{$\begin{array}{c}\text { Conc }(\mu \mathrm{g} / \mathrm{ml}) \\
\text { S. hermonthica } \\
(\mathrm{mm})\end{array}$} & \multicolumn{3}{|c|}{$\begin{array}{c}\text { Conc }(\mu \mathrm{g} / \mathrm{ml}) \\
T . \text { indica } \\
(\mathrm{mm})\end{array}$} & \multicolumn{3}{|c|}{$\begin{array}{c}\text { Conc }(\mu \mathrm{g} / \mathrm{ml}) \\
\text { E. Senegalensis } \\
(\mathrm{mm})\end{array}$} & \multicolumn{3}{|c|}{$\begin{array}{c}\text { Conc }(\mu \mathrm{g} / \mathrm{ml}) \\
V . \text { paradoxa } \\
(\mathrm{mm})\end{array}$} \\
\hline S. Aureus & 13 & 10 & NA & 14 & 12 & NA & 13 & 9 & NA & 12 & 10 & 9 & NA & NA & NA \\
\hline E. Coli & 10 & NA & NA & 12 & 9 & NA & 15 & 12 & 10 & 13 & 12 & NA & 16 & 14 & 11 \\
\hline B. Subtilis & 13 & 9 & NA & 15 & 13 & 11 & 11 & 9 & NA & 14 & 11 & NA & 14 & 12 & 10 \\
\hline K.Pneumonia & 14 & 11 & NA & 11 & 9 & NA & 14 & 11 & 9 & 12 & 10 & NA & NA & NA & NA \\
\hline S. Typhi & 15 & 12 & 9 & NA & NA & NA & 12 & 11 & NA & 13 & 10 & NA & 15 & 12 & 9 \\
\hline C. Albicans & 13 & 11 & $\mathrm{NA}$ & 16 & 14 & 12 & NA & $\mathrm{NA}$ & NA & 10 & 9 & NA & 11 & 10 & NA \\
\hline
\end{tabular}

\section{*NA= NO ACTIVITY *NT= NOT TESTED}

Table1b. Result of Antimicrobial sensitivity test of crude methanol extracts of the samples

\begin{tabular}{|c|c|c|c|c|c|c|c|c|c|c|c|c|c|c|}
\hline \multirow[t]{2}{*}{$\begin{array}{c}\text { Test } \\
\text { organisms } \\
\text { used }\end{array}$} & \multicolumn{3}{|c|}{$\begin{array}{c}\text { CONC }(\mu \mathrm{g} / \mathrm{ml}) \\
\text { E. hirta } \\
(\mathrm{mm})\end{array}$} & \multicolumn{3}{|c|}{$\begin{array}{c}\text { CONC }(\mu \mathrm{g} / \mathrm{ml}) \\
\text { C. mucronata. } \\
(\mathrm{mm})\end{array}$} & \multicolumn{3}{|c|}{$\begin{array}{c}\mathrm{CONC}(\mu \mathrm{g} / \mathrm{ml}) \\
X . \text { americana } \\
(\mathrm{mm})\end{array}$} & \multicolumn{3}{|c|}{$\begin{array}{c}\mathrm{CONC}(\mu \mathrm{g} / 1) \\
W . \text { indica } \\
(\mathrm{mm})\end{array}$} & \multirow{2}{*}{$\begin{array}{c}\text { Ciprofl } \\
\text { oxacin } \\
(30 / \mathrm{ml}) \\
(\mathrm{mm})\end{array}$} & \multirow{2}{*}{$\begin{array}{c}\text { Ketoco } \\
\text { nazole } \\
(30 / \mathrm{ml}) \\
(\mathrm{mm})\end{array}$} \\
\hline & 60 & 30 & 15 & 60 & 30 & 15 & 60 & 30 & 15 & 60 & 3 & 15 & & \\
\hline S. Aureus & 12 & 11 & NA & 13 & 10 & NA & 16 & 14 & 10 & 16 & 12 & 11 & 33 & NT \\
\hline E. Coli & NA & NA & NA & 16 & 14 & 12 & 14 & 10 & NA & 14 & 11 & NA & 28 & NT \\
\hline B. Subtilis & 14 & 10 & NA & NA & NA & NA & 12 & 9 & NA & 12 & 9 & NA & 31 & NT \\
\hline $\begin{array}{c}K . \\
\text { Pneumonia }\end{array}$ & 16 & 13 & 10 & 12 & 10 & 9 & 15 & 12 & 9 & 11 & 10 & NA & 25 & NT \\
\hline S. Typhi & 11 & 9 & NA & NA & 10 & 8 & 13 & 9 & NA & 10 & 9 & NA & 22 & NT \\
\hline C. Albicans & 12 & 10 & 9 & 14 & 10 & 9 & 11 & $\begin{array}{l}\mathrm{N} \\
\mathrm{A}\end{array}$ & NA & 11 & 10 & 9 & NT & 28 \\
\hline
\end{tabular}

*NA= NO ACTIVITY NT= NOT TESTED

Table2. Result of minimum inhibitory concentration (MIC) of the crude extracts

\begin{tabular}{|c|c|c|c|c|c|c|c|}
\hline \multirow[t]{2}{*}{ Plant } & \multirow[t]{2}{*}{ Sample used } & \multirow[b]{2}{*}{$\mathrm{Sa}$} & \multirow[b]{2}{*}{ St } & \multicolumn{4}{|c|}{$\mathrm{MIC}(\mu \mathrm{g} / \mathrm{ml})$} \\
\hline & & & & $\mathrm{Kp}$ & Ec & $\mathrm{Bs}$ & $\mathrm{Ca}$ \\
\hline Waltheria indica & Leaf extract & 15 & 30 & 30 & 30 & 30 & 15 \\
\hline Ximenia Americana & Stem bark extract & 15 & 30 & 15 & 30 & 30 & 60 \\
\hline $\begin{array}{l}\text { Pilostigma } \\
\text { reticulatum }\end{array}$ & Leaf extract & 30 & 15 & 30 & 60 & 30 & 30 \\
\hline Striga hermonthica & Aerial part extract & 30 & - & 30 & 30 & 15 & 15 \\
\hline Vitellaria paradoxa & Leaf extract & - & 15 & - & 15 & 15 & 30 \\
\hline Cissampelos ucronata & Root extract & 30 & 15 & 15 & 15 & - & 15 \\
\hline Euphorbia hirta & Whole plant extract & 30 & 30 & 15 & - & 30 & 15 \\
\hline Tamarindus indica & Root-bark extract & 30 & 30 & 15 & 15 & 30 & - \\
\hline $\begin{array}{l}\text { Erythrina } \\
\text { senegalensis }\end{array}$ & Stem-bark extract & 15 & 30 & 30 & 30 & 30 & 30 \\
\hline
\end{tabular}


Antimicrobial Activity of Some Selected Medicinal Plants in Some Northern Parts of Bauchi State, Nigeria

KEY:Sa=Staphylococcus aureus, $\mathrm{St}=$ Salmonella typhi,Ec $=$ Escherichia coli, $\mathrm{Kp}=$ Klebsiella pneumonia,

$\mathrm{Bs}=$ Bacillus subtilis, $\mathrm{Ca}=$ Candida albicans .

\subsection{Discussion}

Antimicrobial activity of the plants samples were tested against fungal and some bacterial pathogens using agar disc diffusion method (Mangoma, et al., 2010, Atikya, et al., 2014). The result of the antimicrobial sensitivity test was presented in table $1 \mathrm{a} \& \mathrm{~b}$. The minimum inhibitory concentration (MIC) was presented in table 2. The Antimicrobial sensitivity test of crude methanol extracts of the samples indicated that the extracts exhibited varied antimicrobial activity against the tested organisms. The zones of inhibition $(\mathrm{mm})$ ranged from 9-16. The extracts exhibited dose dependent antimicrobial sensitivity test however they were significantly lower than the standard antibiotic drugs ciprofloxacin and Ketoconazole. Ciprofloxacin shown inhibition against the tested organisms with zones range of $22-33 \mathrm{~mm}$ at the concentration of $30 \mu \mathrm{g} / \mathrm{ml}$. Standard antifungal(Ketoconazole) shown inhibition against $C$. albicans with inhibition zone of $28 \mathrm{~mm}$ at the concentration of $30 \mu \mathrm{g} / \mathrm{ml}$.

The whole plant extract of $E$. hirta has shown a greater zone of inhibition $(16 \mathrm{~mm})$ against $K$. Pneumonia, the zone of inhibition ranges from $10-16 \mathrm{~mm}$. The extract has shown the zone of inhibition against $C$. albicans that ranges from $9-12 \mathrm{~mm}$ at the concentration of 15,30 and $60 \mu \mathrm{g} / \mathrm{ml}$ respectively. S. aureus was inhibited with zones of $11-12 \mathrm{~mm}$ for 30 and $60 \mu \mathrm{g} / \mathrm{ml}$. respectively. But the extract has no activity against $S$. aureus at the lowest concentration $(15 \mu \mathrm{g} / \mathrm{ml})$ of test extract. $E$. hirta has zone of inhibition of $10-14 \mathrm{~mm}$ against $B$. subtilis at the concentration 30 and $60 \mu \mathrm{g} / \mathrm{ml}$. respectively. But the extract has no activity against $B$. subtilis at the lowest concentration $(15 \mu \mathrm{g} / \mathrm{ml})$ of test extract. Srilakshmi, et al., (2012) has supported this finding because they reported that the ethanol extracts of E. hirta inhibited the growth of $S$. aureus, S. typhi and E. coli at $25 \mu \mathrm{g} / \mathrm{ml}$ with zones of inhibition of 13.6, 12.8 and $7.2 \mathrm{~mm}$ respectively. S. typhi was inhibited with zones of 9$11 \mathrm{~mm}$ for 30 and $60 \mu \mathrm{g} / \mathrm{ml}$ respectively. But the extract has no activity against $S$. typhi at the lowest concentration $(15 \mu \mathrm{g} / \mathrm{ml})$ of test extract. E. hirta has no activity against E. coli at the tested concentrations. However, this disagreed with the report of Srilakshmi et al., (2012) who reported that the ethanol extracts of $E$. hirta gave zone of inhibition $(7.2 \mathrm{~mm})$ against $E$. coli at $25 \mu \mathrm{g} / \mathrm{ml}$. It might be attributed to differences in environmental factors of location of the sample collection. C. mucronata has shown a greater zone of inhibition $(16 \mathrm{~mm})$ against $E$. coli, the zone of inhibition ranges from 12$16 \mathrm{~mm}$. The extract has shown the zone of inhibition against $K$. pneumonia that ranges from $9-12 \mathrm{~mm}$ at the concentration of 15, 30 and $60 \mu \mathrm{g} / \mathrm{ml}$. respectively. S. Aureus was inhibited with zones of 10$13 \mathrm{~mm}$ for 30 and $60 \mu \mathrm{g} / \mathrm{ml}$. respectively. But the extract has no activity against $S$. aureus at the lowest concentration $(15 \mu \mathrm{g} / \mathrm{ml})$ of test extract. C. mucronata has zone of inhibition of $9-14 \mathrm{~mm}$ against $C$. albicans at the concentration of 15,30 and $60 \mu \mathrm{g} / \mathrm{ml}$ respectively. But the extract has no activity against $B$. subtilis at the lowest concentration $(15 \mu \mathrm{g} / \mathrm{ml})$ of test extract. $S$. typhi was inhibited with zones of $9-11 \mathrm{~mm}$ for 30 and $60 \mu \mathrm{g} / \mathrm{ml}$ respectively. But the extract has no activity against S.typhi at the lowest concentration $(15 \mu \mathrm{g} / \mathrm{ml})$ of test extract. C. mucronata has no activity against $B$. subtilis at the tested concentrations.

The stem bark extract of $X$. americana has shown a greater zone of inhibition $(16 \mathrm{~mm})$ against $S$. aureus, the zone of inhibition ranges from $10-16 \mathrm{~mm}$. The extract has shown the zone of inhibition against $K$. pneumonia that ranges from $9-15 \mathrm{~mm}$ at the concentration of 15,30 and $60 \mu \mathrm{g} / \mathrm{ml}$. respectively. But the extract has no activity against E. coli and B. subtilis at the lowest concentration $(15 \mu \mathrm{g} / \mathrm{ml})$ of the test extract. However the extract shown zone of inhibition that ranges from 10$14 \mathrm{~mm}$ and $9-12 \mathrm{~mm}$ of $E$. coli and B. subtilis respectively. This finding agreed with study of Maikai, et al (2009) that reported that both butanol and methanol stem bark extracts of X. Americana showed activity against $E$ coli, $S$. aureus and $B$. subtilitis. The stem bark extract of $X$. americana has zone of inhibition of $11 \mathrm{~mm}$ against $C$. albicans at the concentration of $60 \mu \mathrm{g} / \mathrm{ml}$ only. But the extract has no activity against $C$. albicans at the concentration of $30 \mu \mathrm{g} / \mathrm{ml}$ and $15 \mu \mathrm{g} / \mathrm{ml}$ of test extract. This is supported by a similar study by Maikai, et al., (2009) who reported that the methanol and water extracts of stem of $X$. americana exhibited activity against candida albicans. S. typhi was inhibited with zones of 9 and $13 \mathrm{~mm}$ for 30 and $60 \mu \mathrm{g} / \mathrm{ml}$ respectively. But the extract has no activity against $S$. typhi at the lowest concentration $(15 \mu \mathrm{g} / \mathrm{ml})$ of test extract. 
Antimicrobial Activity of Some Selected Medicinal Plants in Some Northern Parts of Bauchi State, Nigeria

The leaf extract of $W$. indica has shown a greater zone of inhibition $(16 \mathrm{~mm})$ against $S$. aureus at the highest concentration and zone of inhibition ranges from $11-16 \mathrm{~mm}$ for all tested pathogens. The extract has shown the zone of inhibition $(9,10$ and $11 \mathrm{~mm})$ against $C$. albicans at the concentration of 15,30 and $60 \mu \mathrm{g} / \mathrm{ml}$ respectively. E. coli, B. subtilis, K. pneumonia and S. typhi were only inhibited at higher concentrations of 30 and $60 \mu \mathrm{g} / \mathrm{ml}$. But the extract has no activity against $E$. coli, $K$. pneumonia, S. typhi and B. subtilis at the lowest concentration of $15 \mu \mathrm{g} / \mathrm{ml}$. In a similar study conducted the ethanol extract of leaves of W. indica inhibited the growth of E. coli, S. typhi and $S$. aureus with inhibition zones of $10 \pm 1,12 \pm 1$ and $13 \pm 1 \mathrm{~mm}$ respectively (Olajuyigbe et al., 2011).

The leaf extract of $P$. reticulatum has shown a greater zone of inhibition $(16 \mathrm{~mm})$ against $S$. typhi, the zone of inhibition ranges from $9-15 \mathrm{~mm}$. The extract has shown the zone of inhibition (11 and $13 \mathrm{~mm})$ against $C$. albicans at the concentration of 30 and $60 \mu \mathrm{g} / \mathrm{ml}$ respectively. The extract shown inhibition at higher concentration against $E$. coli with zone of $10 \mathrm{~mm} \mathrm{~B}$. subtilis was inhibited at concentration of 30 and $60 \mu \mathrm{g} / \mathrm{ml}$ with zone of 9 and $13 \mathrm{~mm}$ respectively. K. pneumonia was inhibited at concentration of 30 and $60 \mu \mathrm{g} / \mathrm{ml}$ with zone of 11 and $14 \mathrm{~mm}$ respectively. E. coli was only inhibited at higher concentrations of $60 \mu \mathrm{g} / \mathrm{ml}$ with zone of $10 \mathrm{~mm}$. But the extract has no activity against E. coli, $K$. pneumonia, S. aureus, $C$. albicans and $B$. subtilis at the lowest concentration of $15 \mu \mathrm{g} / \mathrm{ml}$. In a similar study it was reported that the ethanolic leaf extract of $P$. reticulatum showed broad antimicrobial activity against $S$. aureus, E. coli and $S$. typhi (Olusola, et al., 2011).

The aerial parts extract of $S$. hermonthica has shown a greater zone of inhibition (16mm) against $C$. albicans the zone of inhibition ranges from $12-16 \mathrm{~mm}$. The extract has shown the zone of inhibition $(12,14$ and $16 \mathrm{~mm})$ against $C$. albicans at the concentration of 30 and $60 \mu \mathrm{g} / \mathrm{ml}$ respectively. This result disagreed with the findings of Elshiek and Mona, (2015) in which they reported that the ethanol extract of the whole plant was not active against $C$. albicans. This might be attributed to differences in environmental conditions. The extract also shown inhibition against $B$. subtilis at all tested concentrations with the inhibition zones of 11,13 and $15 \mathrm{~mm}$ respectively. K. pneumonia was inhibited at concentration of 30 and $60 \mu \mathrm{g} / \mathrm{ml}$ with zones of 9 and $11 \mathrm{~mm}$ respectively. E. coli was also inhibited at concentrations of 30 and $60 \mu \mathrm{g} / \mathrm{ml}$ with zones of 9 and $12 \mathrm{~mm}$ respectively. S. aureus was also inhibited at concentrations of 30 and $60 \mu \mathrm{g} / \mathrm{ml}$ with zones of 12 and $14 \mathrm{~mm}$ respectively. But the extract has no activity against $S$. typhi at the tested concentrations. In a similar study carried out on the extracts of S. hermonthica against Staphylococcus aureus, Bacillus subtilitis, Escherichia coli, and Candida albicans revealed that ethanol extract of the whole plant showed moderate activity against the tested bacteria but showed no activity against Candida albicans (Elshiek and Mona, 2015).

$T$. indica has shown a greater zone of inhibition $(15 \mathrm{~mm})$ against $E$. coli, the zone of inhibition ranges from $10-15 \mathrm{~mm}$. The extract has shown the zones of inhibition $(10,12$ and $15 \mathrm{~mm})$ against $E$. coli at the concentration of 15,30 and $60 \mu \mathrm{g} / \mathrm{ml}$ respectively. The extract also shown inhibition at against $K$. pneumonia at all tested concentrations with the inhibition zone of 9,11 and $14 \mathrm{~mm}$. B. subtilis was inhibited at concentration of 30 and $60 \mu \mathrm{g} / \mathrm{ml}$ with zone of 9 and $11 \mathrm{~mm}$ respectively. S. typhi was also inhibited at concentrations of 30 and $60 \mu \mathrm{g} / \mathrm{ml}$ with zones of 9 and $12 \mathrm{~mm}$ respectively. $S$. aureus was also inhibited at concentrations of 30 and $60 \mu \mathrm{g} / \mathrm{ml}$ with zones of 9 and $13 \mathrm{~mm}$ respectively. But the extract has no activity against $C$. albicans at the tested concentrations. This finding agreed with the results of Kapur and John (2014) who reported the antimicrobial activity of ethanolic bark extracts of Tamarindus indica against growth inhibition of S. aureus, K. pneumonia and $E$. coli with inhibition zones of 16,13 and $12 \mathrm{~mm}$ respectively.

E. senegalensis has shown a greater zone of inhibition $(14 \mathrm{~mm})$ against B. Subtilis, the zone of inhibition ranges from $11-14 \mathrm{~mm}$. The extract has shown the zones of inhibition (12 and $14 \mathrm{~mm})$ against $B$. subtilis at the concentration of 30 and $60 \mu \mathrm{g} / \mathrm{ml}$ respectively. The extract also shown inhibition at against $S$. aureus at all tested concentrations with the inhibition zones of 9,10 and $12 \mathrm{~mm}$. k. pneumonia was inhibited at concentration of 30 and $60 \mu \mathrm{g} / \mathrm{ml}$ with zone of $10 \mathrm{and} 12 \mathrm{~mm}$ respectively. S. typhi was also inhibited at concentrations of 30 and $60 \mu \mathrm{g} / \mathrm{ml}$ with zones of 10 and $13 \mathrm{~mm}$ respectively. E. coli was also inhibited at concentrations of 30 and $60 \mu \mathrm{g} / \mathrm{ml}$ with zones of 12 and $13 \mathrm{~mm}$ respectively. C. albicans was also inhibited at concentrations of 30 and $60 \mu \mathrm{g} / \mathrm{ml}$ with zones of 9 and $10 \mathrm{~mm}$ respectively. However the extract has no activity at the lowest tested concentration $(15 \mu \mathrm{g} / \mathrm{ml})$ against all the organisms except $S$. aureus. The results agreed with a similar 

Nigeria

research on the antimicrobial activity of methanol, chloroform and aqueous stem back extracts of Erythrina senegalensis using the filter paper disc diffusion method in which the extracts demonstrated antimicrobial activity against Staphylococcus aureus, Escherichia coli, Salmonella typhi, and Candida albicans (Doughari, 2010).

The leaf extract of $B$. paradoxum has shown a greater zone of inhibition $(16 \mathrm{~mm})$ against $E$. coli the zone of inhibition ranges from $11-16 \mathrm{~mm}$. The MIC of the extract against E. coli, S. typhi and $B$. subtilis is $15 \mu \mathrm{g} / \mathrm{ml}$ and $30 \mu \mathrm{g} / \mathrm{ml}$ for C. albicans. However the extract has no activity at all tested concentrations against $S$. aureus and $k$. pneumonia. The extract has shown the zones of inhibition (11, 14 and $16 \mathrm{~mm}$ ) against $E$. coli at the concentration of 15,30 and $60 \mu \mathrm{g} / \mathrm{ml}$ respectively. The extract also shown inhibition at against $S$. typhi at all tested concentrations with the inhibition zone of 9,12 and $15 \mathrm{~mm}$. B. subtilis was inhibited at concentration of 15,30 and $60 \mu \mathrm{g} / \mathrm{ml}$ with zone of 10,12 and $14 \mathrm{~mm}$ respectively. S. typhi was also inhibited at concentrations of 30 and $60 \mu \mathrm{g} / \mathrm{ml}$ with zones of 10 and $13 \mathrm{~mm}$ respectively. C. albicans was also inhibited at concentrations of 30 and $60 \mu \mathrm{g} / \mathrm{ml}$ with zones of 10 and $11 \mathrm{~mm}$ respectively. This result agreed with the findings of Kubmarawa et al., (2007) who reported the antimicrobial activity of stem bark of B. paradoxum on the similar pathogens but the stem bark extract was active against $S$. aureus while in this work the leaf extract has no activity against $S$. aureus. This could be due to different parts of the plant used in the study, here leaves were used not the stem bark of the plant. Olajuyigbe, et al (2011) reported that zones of inhibition $\geq 10 \mathrm{~mm}$ were considered as good antimicrobial activity for the crude plant extracts. Thus, several extracts used in the study have exhibited zones of inhibition greater than $10 \mathrm{~mm}$ and they are recommended for further screening to isolate and characterize the bioactive chemical constituents.

\section{CONCLUSION}

The chemical constituents tested in the plants were the major therapeutic agents found in medicinal plants. Therapeutic activity against most diseases caused by pathogenic infections could be attributed to the present of these bioactive agents. The extracts have demonstrated significant inhibitory activity against the tested organisms even though some extracts are inactive. Therefore, the active plants extracts can act as potential source of compounds or "lead-compounds" for development of antimicrobial agents that could be useful in chemotherapy.

\section{ACKNOWLEDGEMENT}

The authors wish to thank the HOD chemistry, Modibbo Adama University of Technology, Yola, Nigeria and both Academic and non academic staff of the department for their support and contribution in this research. We are particularly grateful to the management and staff of Mallam Aminu Kano University Teaching Hospital, Kano Nigeria for their assistance during the antimicrobial studies. We are also grateful to mallam Umar of the Microbiology Laboratory of Bayero University Kano (BUK) Nigeria for his technical assistance in the antimicrobial research. We also acknowledge the support of the management of Aminu Saleh college of Education Azare, Bauchi state Nigeria in the provision of the necessary facilities throughout the research.

\section{REFERENCES}

[1] Abdalfatah, A., Sajan L. S., Christina Y. I. and Saad, M. H. A. (2013). Bioassay and Phytochemical Studies on Ximenia Americana L. Bark Ethanolic Extract. J. Forest Products and Industries. 2(3) : 63-68.

[2] Akinniyi, I. A. and Tella, U. A. (1991). Rural resources and national development(part II). A case for the recognition of African traditional medicines in Nigeria. Annals of Borno. 6/7:279-293.

[3] Aska, A. S. and Kubmarawa, D. (2016). Preliminary phytochemical screening of some indigenous medicinal plants used in the treatment of tuberculosis in Bauchi state, Nigeria. IOSR- Journal Applied Chemistry. 9:(4)1:48-52.

[4] Atikya, F., Nagma, Z., M.D., Shahidul, K. (2014). Antimicrobial activity of medicinal plant leaf extracts against pathogenic bacteria. Asian Pac. J. Trop. Dis. ; 4 (Suppl 2): S920-S923, Pp 1-5

[5] Copp, B.R. (2003). The Review of Natural Products with antimicrobacterial activity. Nat.Prod. Report, 20:535-557.

[6] Doughari, J. M. (2010). Evaluation of antimicrobial potentials of stem bark extracts of Erythrina senegalensis DC. Afri. J. Microbio. Res. 4(17):1836-1841.

[7] Elshiek, Y. H and Mona, A. M. A. (2015). Phytochemical screening and antimicrobial activity of striga hermonthica and Nigella sativa seeds. American J. Res. Comminication. Pp 24-33. 
Antimicrobial Activity of Some Selected Medicinal Plants in Some Northern Parts of Bauchi State, Nigeria

[8] Hamza, O.J. and Mbwabo, Z.H. (2006). Antifungal activity of some tanzanian plants used in traditionally for the treatment of fungal infections. J. Ethnopharm. 108:124-134.

[9] Ibrahim, T. B., Esther, A. A., Yuehong, W. and Francis, O. S. (2012). Anti-TB Activity of Sterculia setigera Del., Leaves. J. Pharmacognosy and Phytochemist. 1(3):17-23.

[10] Katerere, D.R., Gray A.I., Nash, R.J. and Waigh, R.D. (2003). Antimicrobial activity of pentacyclic triterpenes isolated from African Combretaceae. Phytochemistry 63: 81-88.

[11] Kapur, A. M. and John A. S. (2014). Antimicrobial activity of ethanolic bark extract of Tamarindus indica against some pathogenic microorganisms. Int. J. Curr. Microbiol. App. Sci. 3(3): 589-593.

[12] Koné, W.M., Atindehou, K.K., Terreaux, C., Hostettmann, K.,Traoré, D. and Dosso, M. (2004). Traditional medicine in north Côte-d'Ivoire: screening of 50 medicinal plants for antibacterial activity. J. Ethnopharmacol. 93(1): 43-49.

[13] Koua, F. H. M., Babiker, H. A., Halfawi, A., Ibrahim, R. O., Abbas, F. M., Elgaali E.I.(2011).Phytochemical and Biological Study of Striga hermonthica(Del.)Benth callus and intact plant. Res. Pharm. Biotechnol. 3(7):85-92.

[14] Kubmarawa, D.,Ajoku, G. A., Enwerem, N. M. and Okorie, D. A. (2007). Preliminary phytochemical and antimicrobial screening of 50 medicinal plants from Nigeria. African J. Biotechnology. 6 (14): 1690- 1696.

[15] Mangoma, N., Saidi, B. and Mbanga, J. (2010). An evaluation of the antimicrobial activities of Aloe barbadensis: A. chabaudii and A. arborescens leaf extracts used in folklore veterinary medicine in Zimbabwe. J. Anim. and Vet. Adv. 9(23):2918-2923.

[16] Maikai, VA, Maikai, BV and Kolo, PI. (2009). Antimicrobial properties of stem bark extracts of X. americana. J. Agric. Sci. 1(2):30-34.

[17] Mann, A., Gbate, M. and Nda-Umar, A. (2003). Medicinal and Economic Plants of Nupeland. 1st edn. Jube-Evans books and Publications, Bida. Pp . 279.

[18] Newman, N.P. (2006). Plant and human health in the twenty first century. Trends biotechnol. 10:511-531.

[19] Ogundaini, A. O. (2005). "From greens into Medicine taking a lead from Nature" Inaugural lecture series 176 Obafemi Awolowo University Press Ltd. Ile-Ife, Nigeria. Pp 1-10.

[20] Olusola, A., Olajide O. O., Afolayan, M. and Arifalo, K. M.(2011). Preliminary phytochemical and antimicrobial screening of the leaf extract Pilostigma reticulatum (dc) Hochst. Afr. J. Pure and Applied Chem. 5(3), pp. 43-46.

[21] Okwute, S. K., Olakunle, A., F., Orishadipe, A. T. (2017.) Phytochemical Screening and in Vitro Antimicrobial Activity of Waltheria Indica Linn Leaf Extracts. Biomedical Sciences. Vol. 3, No. 5, pp. 86-93

[22] Sanogo, R. (2005). Antifungal and Antioxidant Activities of 14 plants used in the Treatment of Sexually Transmitted Infections. A paper presented at Western Africa Network of Natural Products Research Scientists (WANNPRES), first scientific meeting August, 15-20, 2004.Accra, Ghana: A report. Afr. J. Trad, Complem. Alter. Med. 2(2): 177- 205.

[23] Sofowora, A. (1993). Medicinal plants and Traditional Medicine in Africa. 2nd edn. Spectrum books Ltd, Ibadan. Pp 1-5, 50-91.

[24] Srilakshmi, M., Saravanan, R., Dhachinamoorthi, D., Senthilkumar, K. and Divya Sri, T. (2012). Antibacterial activity of Euphobia hirta extracts. IJRAP 3(3): 439-441.

[25] Tanaka, H., Sudo, M., Kawamura, T., Sato, M., Yamaguchi, R., Fukai, T. (2010). Antibacterial constituents from the roots of Erythrina herbacea against methicillin-resistant Staphylococcus aureus. Planta Med. 76(9): 916-919.

[26] Zailani, A. H., Jada, S. M. and Wurochekke, U. A. (2010). Antimicrobial Activity of Waltheria Indica. Journal of American Science. 6 (12):1591-1594.

Citation: Aska A.S, et.al., (2019). "Antimicrobial Activity of Some Selected Medicinal Plants in Some Northern Parts of Bauchi State, Nigeria”. International Journal of Advanced Research in Chemical Science (IJARCS), 6(5), pp.1-7. DOI: http://dx. doi.org / 10.20431/2349-0403.0605001.

Copyright: (C) 2019 Authors. This is an open-access article distributed under the terms of the Creative Commons Attribution License, which permits unrestricted use, distribution, and reproduction in any medium, provided the original author and source are credited. 